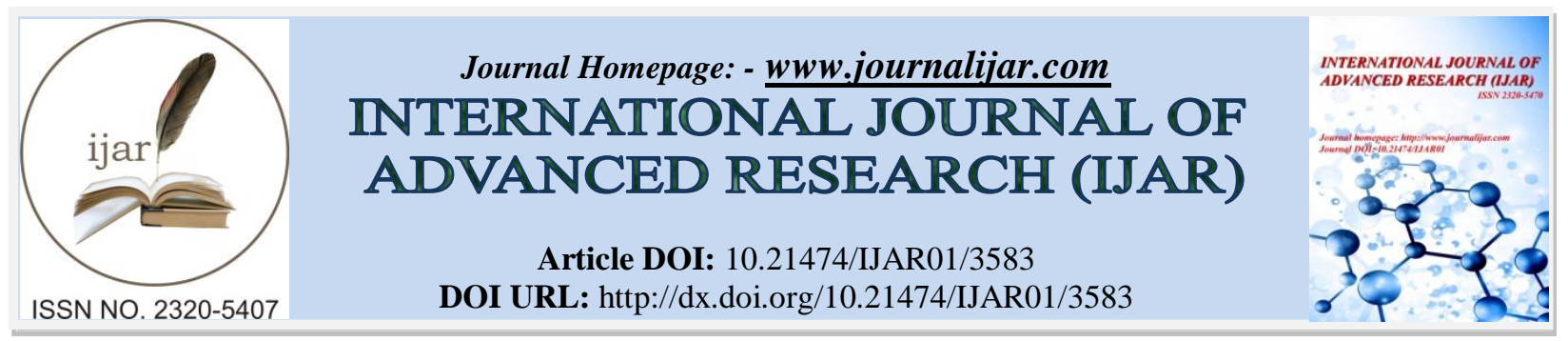

RESEARCH ARTICLE

\title{
POSTNATAL DEVEOPMENT OF BRUNNER'S GLAND IN RABBIT
}

\author{
Dr. Mrs. Meena Goyal ${ }^{1}$ and Dr . Mrs. K. Pandher ${ }^{2}$. \\ 1. Professor, Dept. of Anatomy, Pt. JNM Medical College, Raipur (C.G) \\ 2. Retd. Professor and HOD Dept. of Anatomy G.R. Medical College, Gwalior (M.P.)
}

\section{Manuscript Info}

Manuscript History

Received: 04 January 2017

Final Accepted: 06 February 2017

Published: March 2017

\section{Abstract}

Introduction- Brunner's glands are located in the submucosa of the duodenum in all mammals. The principal function of the glands is thought to be protection of the duodenal mucosa against the erosive effects of the gastric juice by virtue of the mucoid nature of its secretion, its alkalinity, and possibly by the buffering capacity of its bicarbonate content In the present study postnatal development of Brunner's glands in the rabbit was observed in 21 rabbits

Material \& methods- This research work was done during the period between1977-1979 as a part of thesis work. The present work, postnatal development of the duodenal submucosal glands in the four parts of the duodenum was studied in rabbit. Method-For postnatal developmental study of Brunner's glands in rabbit animals were used either the littermates or the young ones of the same parents. Rabbits of 0hrs, 1 week,2weeks,3weeks, 4 weeks, 5 weeks, and 6 weeks age formed one series. Three such series were examined .Four pieces were taken from first, second, third and fourth part of duodenum and placed in fixative $10 \%$ formal saline. Tissues were processed routinely and stained with : haematoxylin and eosin for light microscopy.

Results- The origin and development of Brunner's glands in the rabbit have been studied in postnatal animals. Brunner's glands arise principally from the bases of crypts of Lieberkuhn. The glands commence as buds which proliferate deep into the submucosa and branch to give rise to tubules and to a duct system. The Brunner's glands in rabbit extended up to the second part of duodenum at birth and their extent gradually increased distally By the end of second week the glandular tissue reached the fourth part of duodenum .The glands were more in the proximal part of duodenum and decreased from the proximal to the distal part .Compactness of glands when traced at weekly intervals in the identical parts of duodenum showed marked increase upto sixth week.The serous cells were differentiated in the terminal portions of tubules at birth but mucous acini started differentiated only after two weeks

Copy Right, IJAR, 2017,. All rights reserved. 


\section{Introduction:-}

The duodenal glands or the glands of Brunner are present in all mammals and are believed to secrete an alkaline fluid containing mucin. The duodenal glands were first observed in 1679 by Wepfer ${ }^{1}$ who described them during the autopsy.. Wepfer ${ }^{1}$ described their arrangement in the duodenum and observed that when they were macerated in water, the duodenal glands discharged copious amounts of mucus. Nine years later, Brunner ${ }^{2,3}$ who was Wepfer's son-in-law, described the duodenal glands in the horse, ox, sheep, deer, dog, and beaver and presented a brief description in man. Brunner considered these glands to be accessory pancreatic tissue and termed them "glandulae duodeni" or "pancreas secundarium." Middeldorpf ${ }^{(5)}$ realized that the secretion of the duodenal glands differed from that of the pancreas and suggested that these glands be designated "the glands of Brunner." Florey and Harding (6,7) found that the region of the duodenum containing the duodenal glands is more resistant to acid erosion than other regions of the small intestine. Grossman ${ }^{(8)}$ in 1958 has reviewed the literature with regard to these glands and recent studies Moe, 1960; ${ }^{(9)}$, Cochrane,Davies, Palfrey \& Stockwell, 1964; ${ }^{(10)}$ Friend, 1965 ${ }^{(11)}$ Leeson \& Leeson, $1966^{(12)}$ have reported upon the fine structure of the glands in cat, guinea-pig, mouse and rat respectively. The latter studies have emphasized species differences. In the cat and in the mouse, gland cells possess features intermediate between those of mucous and serous cells. Component cells of the glands in the guinea-pig are typically mucous in type and in the rat cells appear to be more mucous than serous with regard to their fine structural appearance.Little work has been reported on the development of Brunner's glands. Barth $(1868)^{(13)}$ reported that in the rabbit the duodenal glands sprout off from the crypts of Lieberkuhn as double outgrowths. In man, the glands first appear at approximately78 mm (3 months) (Brand, 1877; ${ }^{(14)}$ Johnson, 1910 ${ }^{(15)}$ ) and arise from the bottoms of the crypts of Lieberkuhn. The glands develop in a progressive fashion starting in the upper one-third of the duodenum and extending downward so that in the $120 \mathrm{~mm}$ stage the greater part of the duodenum contains glands of Brunner. As the glands develop they branch several times, each branch becoming arranged into a lobule. The present paper reports upon the postnatal development of the Brunner's glands in the rabbit .

\section{Material and methods:-}

This research work was done during the period (!977--1979).as a part of thesis work. Twenty one rabbits divided into seven specific age groups were used in this study. For postnatal developmental study of Brunner's gland in rabbit, animals were used either the littermates or the young ones of the same parents .Rabbits of 0hrs, 1 week,2weeks, 3weeks, 4 weeks,5weeks, and 6weeks age formed one series. Three such series were examined. The animals were anesthesized by giving ether. Entire duodenum was removed from pyloro duodenal junction to duodenojejunal junction in each rabbitt. Four pieces were taken from first, second, third and fourth part of duodenum and placed in fixative $10 \%$ formal saline. Tissues were processed routinely and stained with Haematoxylin and Eosin for light microscopy.

\section{Results:-}

Postnatal development of Brunner's gland in four parts of duodenum was studied in rabbits from birth(zero hour) upto six weeks of life.

Zero Hour-Tubular structures lined with stratified cuboidal epithelium having two cell layers were scattered in the sub-mucosa throughout its circumference in the first part of duodenum. Branching of tubules and their continuity with deeper parts of intestinal glands was seen at places(Fig.1).Related with the tubules, ill defined serous acinar cells were evident.Similar tubular structures but in reduced number were also seen in the submucosa of second part of duodenum and were not seen in the submucosa of third and fourth part of duodenum at all Muscularis mucosae was seen as a fine interrupted streak like structure.

First Week-Tubular structures were seen in the greater number than that at zero hours in the submucosa of first and second part of duodenum .Few tubular structures were also seen in the submucosa of third part of duodenum but were not seen in the submucosa of fourth part of duodenum. Muscularis mucosae was seen as a thin interrupted line.

Second week-Tubular structures were seen in the increased number in the submucosa of first, second and third part of duodenum than that at first week. Few tubular structures were also seen in the submucosa of fourth part of duodenum also.(Fig.2)

Third Week-Glandular tissue in increased number with well differentiated acini were seen in the submucosa of all 
parts of duodenum.In the first part well differentiated mucous acini were more in number

(Fig 3) while in second and third part serous acini were more than mucous acini and only serous acini were seen in fourth part(Fig.4).In the first part glanduar tissue was more dense. Ducts of the gland lined with simple cuboidal epithelium and opening into the deeper parts of intestinal glands were also seen. Well developed muscularis mucosae was observed in all parts.

Fourth Week-Well differentiated glandular tissue with increased quantity were seen in in the submucosa of all parts in comparision to that at third week(Fig 5).It was most dense in first part and very less in fourth part.There was predomination of mucous acini in the first part and of serous acini in the second , third and fourth part.In the fourth part mucous acini were rarely seen.

Fifth week-Glandular tissue in the submucosa was more in comparision to that at four weeks in all parts.Predomination of mucous acini was observed in the first part and of serous acini in the third part and fourth part while of both mucous and serous acini in second part.

Sixth week-Glandular tissue in the submucosa was more in comparision to that at fifth week in all parts.Glandular lobules were seen in the submucosa as well as in the lamina propria of first part of duodenum (Fig6) Gradual decrease in density was observed in distal parts of duodenum .Predomination of mucous acini in the first and second part of duodenum(Fig.7)and of serous acini in the fourth part( Fig8)was seen. While in the third part mucous and serous acini were almost in equal proportion.

\section{Discussion:-}

In the present work postnatal development of Brunner's glands were studied in rabbits from birth to six weeks of age. The Brunner's gland in the rabbit at birth was represented by two cell layered tubular growth from the deeper parts of intestinal gland,branching into the submucosa in the present study( fig.1) The Brunner's glands in rabbit extended upto the second part of duodenum at birth and their extent gradually increased distallyBy the end of second week the glandular tissue reached the fourth part of duodenum (fig.2)..Obouforibo and Martin ${ }^{(16)}$ (1977) also described similar stage of glandular tissue in the newborn mouse Krause and Leeson $\left.{ }^{(17)(} 1967\right)$, however mentioned that rat possessed all the mucosal constituents of duodenum at birth and it only differed in the extent and degree of differentiation of various structures in adults. The duodenal glands in the golden hamster developed on the first day after birth( Mann et al.1967) ${ }^{(18)}$ and reached functional maturity by the fifteenth postnatal day.. Woff ${ }^{(22)(1961)}$ found that glands first appeared near the pylorus and developed pari passu with the duodenum. Krause and Leeson(1967) ${ }^{(17)}$ working on rat , also mentioned that the development and differentiation of Brunner's gland followed a progressive pattern,slowly extending down the duodenum till the final distribution was reached Adult stage was achieved by third week in mouse (Obouforibo and Martin, 1977) ${ }^{(16)}$.With the increasing downward extent, the compactness of glands in the proximal part was found to be increased in the present work. Similar observations were found by Obouforibo and $\operatorname{Martin}(1977)^{(17)}$ in the mouse. Mohammadpour, A. A.,(19) also found in the guinea pig the glands were well developed in the cranial part of duodenum. There was a significant difference in the thickness of duodenal submucosal glands in all parts of the duodenum that decreased from the cranial to the ascending part. In the present study compactness of glands when traced at weekly intervals in the identical parts of duodenum showed marked increase upto sixth week.( fig.4 \& 6) .Obouforibo and Martin(1977) ${ }^{(17)}$ mentioned that the growth rate of glands in mouse was found to be diminished after third week. Cooke $(1967)^{(20)}$ mentioned that the serous cells differentiated a day before birth and mucous cells were four to five days after birth.In the present study also the serous cells were differentiated in the terminal portions of tubules at birth.(fig.1) but mucous acini started differentiated only after two weeks.Gabe $(1956)^{(21)}$ showed that all the cells of submaxilary glands were serous at birth and five days after changed to mucous type.In the present study no such things were found.

Florey and Harding (1933) $)^{(6)}$ and Cooke $(1967)^{(20)}$ mentioned that the secretion of the Brunner's glands being alkaline in nature protected the duodenum from ulceration by acid pepsin.In the present study at sixth week predomination of mucous acini in the first(Fig.6) and second part of duodenum (Fig.7)and of serous acini in the fourth part (Fig 8) was seen. While in the third part mucous and serous acini were almost in equal proportion.So the proximal part of duodenum showed large proportion of mucous acini as compared to the distal part. This could be correlated to the greater need of alkanity in the vicinity of pyloric region which is the first to receive the acidic content of the stomach. 


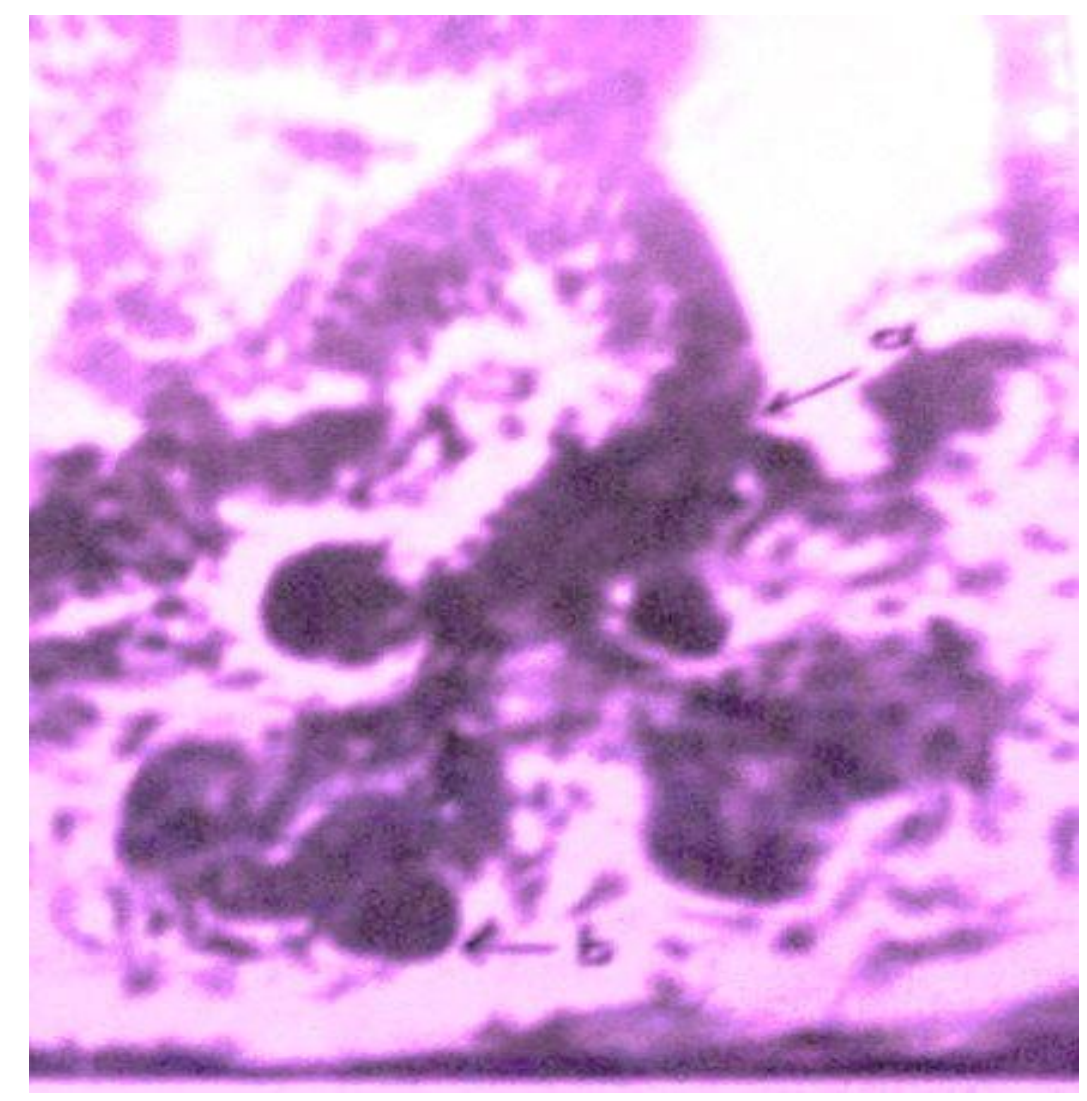

Fig. 1Rabbit -Zero hour-H\&E stain x500 Photomicrograph of T.S, of First part of duodenum showing a) branching of tubules and their continuity with deeper parts of intestinal glands

b) muscularis mucosae . 


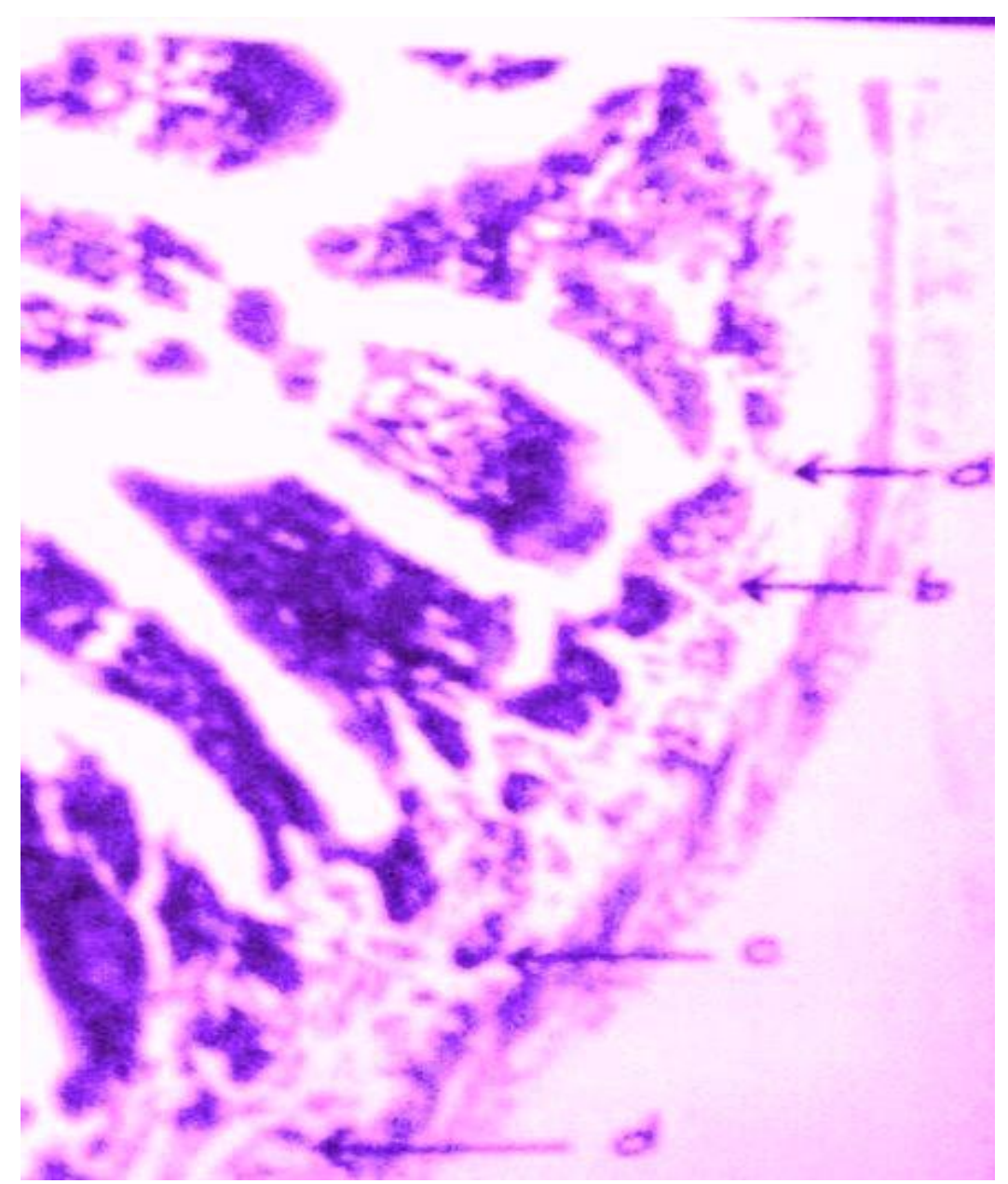

Fig. 2 Rabbit-Second week(H \&E stain x80) Photomicrograph of T.S, of fourth part of duodenum showing a) submucosa

b) muscularis mucosae

c) ill defined seros acini

d) tubular structure 


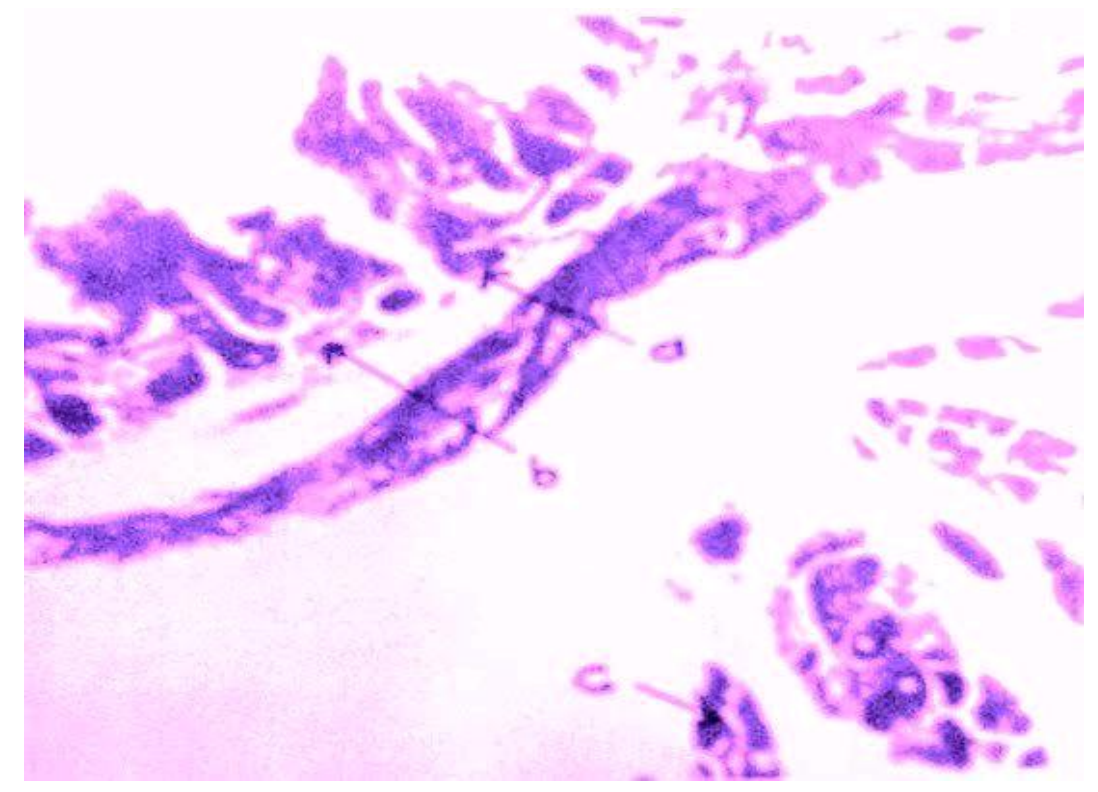

Fig.3 Rabbit-Third week(H \&E stainx80) Photomicrograph of T.S, of fourth part of duodenum showing a) submucsa having few serous acini

b) muscularis mucosae

c) pancreatic acini

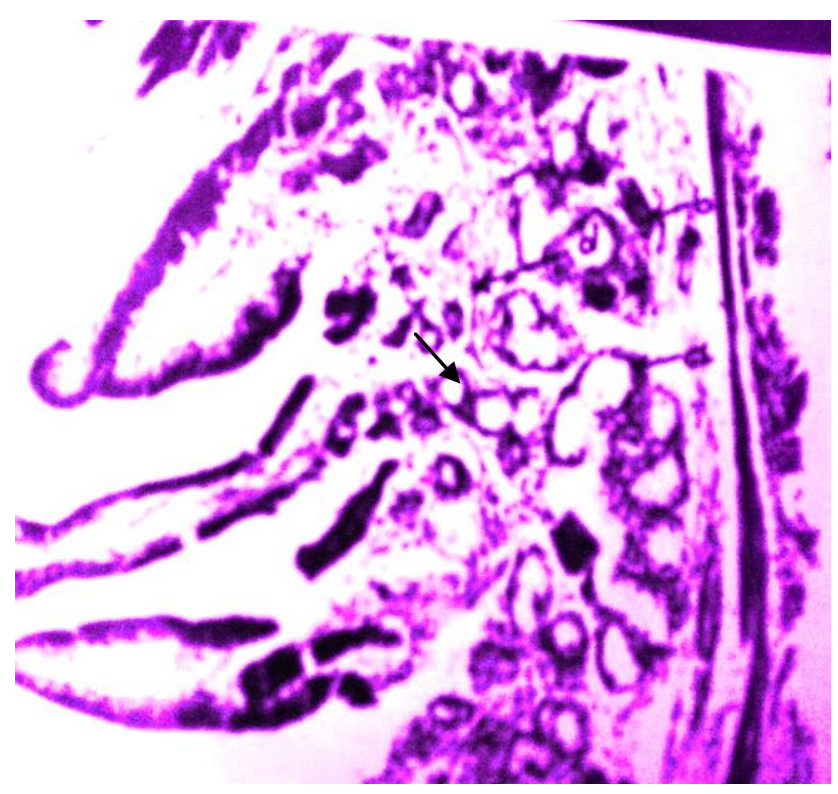

Fig. 4 Rabbit-Third week(H \&E stain x80) Photomicrograph of T.S, of first part of duodenum showing-

a) well differentiated mucous acini in the submucsa

b) serous acini

c) mucous acini in the lamina propria(arrow)

d) muscularis mucosae 


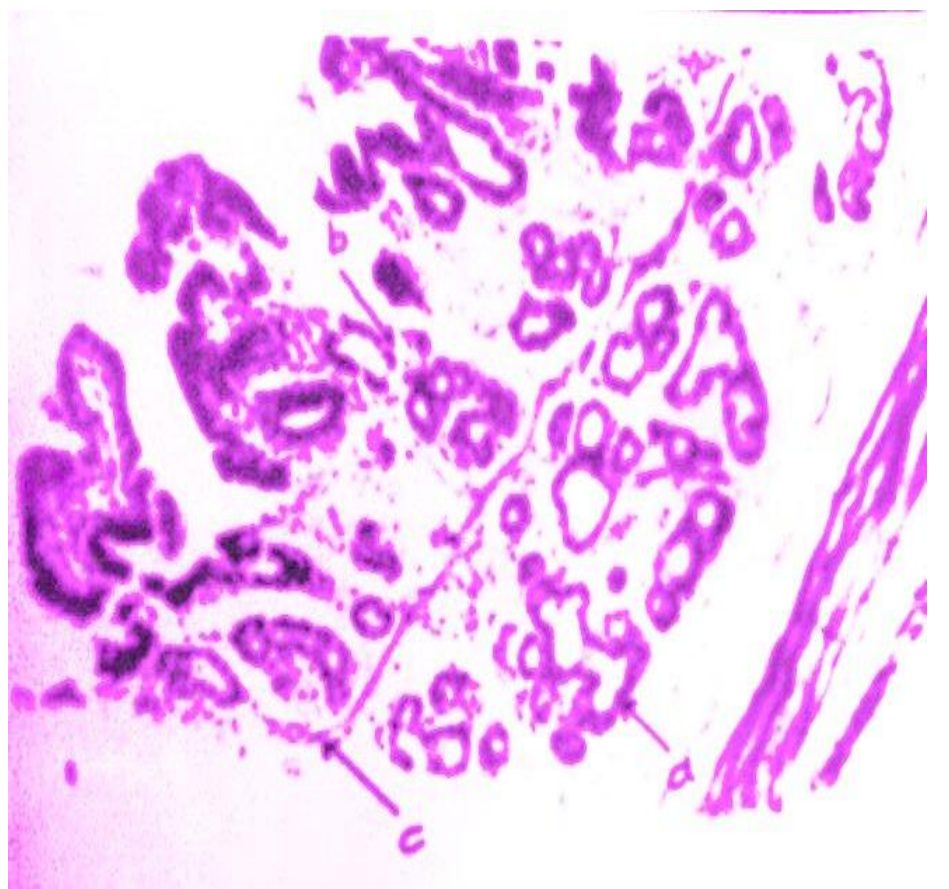

Fig. 5 Rabbit Fourth week (H \&E stain) Photomicrograph T.S, of first part of duodenum showing

a) glandular lobules in the submucosa

b) glandular lobules in the lamina propria

c) muscularis mucosae

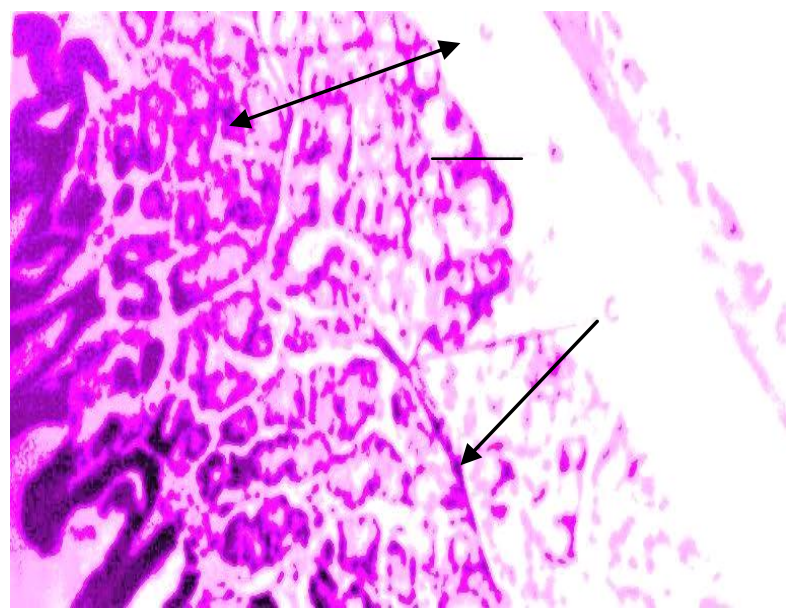

Fig.6 Rabbit-Six weeks(H \&E stain x80) Photomicrograph T.S, of first part of duodenum showing a) glanduar lobules in the lamina propria (double arrow)

b) glanduar lobules in the submucsa (line)

c) muscularis mucosae branching and forming the network occupied by glandular lobules(arrow) 


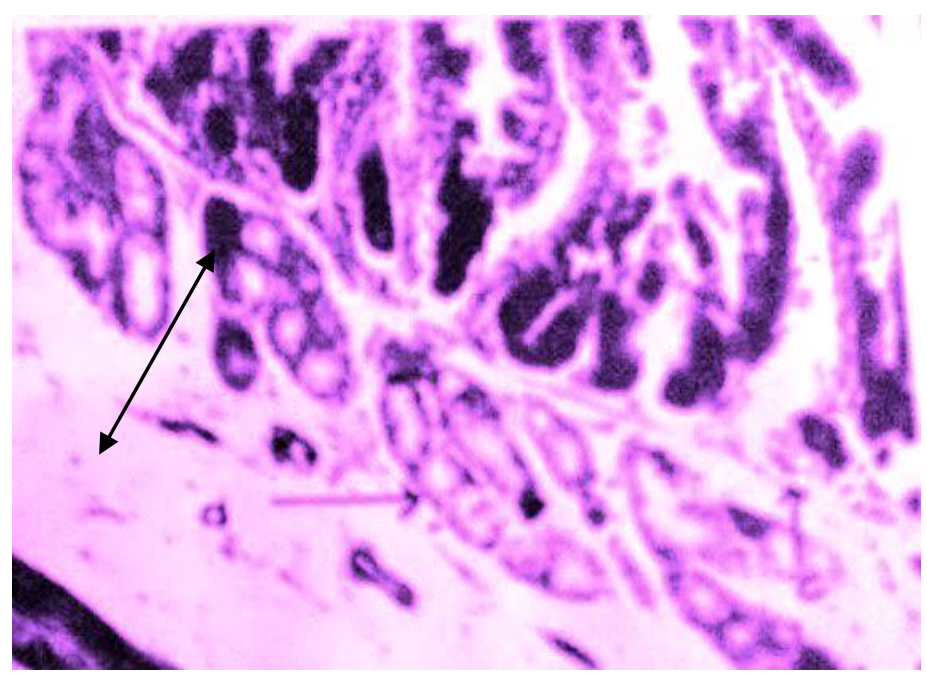

Fig.7 Rabbit-Six weeks(H \&E stainx80) Photomicrograph of T.S, of second part of duodenum showing-

a) mucous acini forming major part of glandular tissue in the submucosa

b) occasional serous acini (double arrow)

c) muscularis mucosae

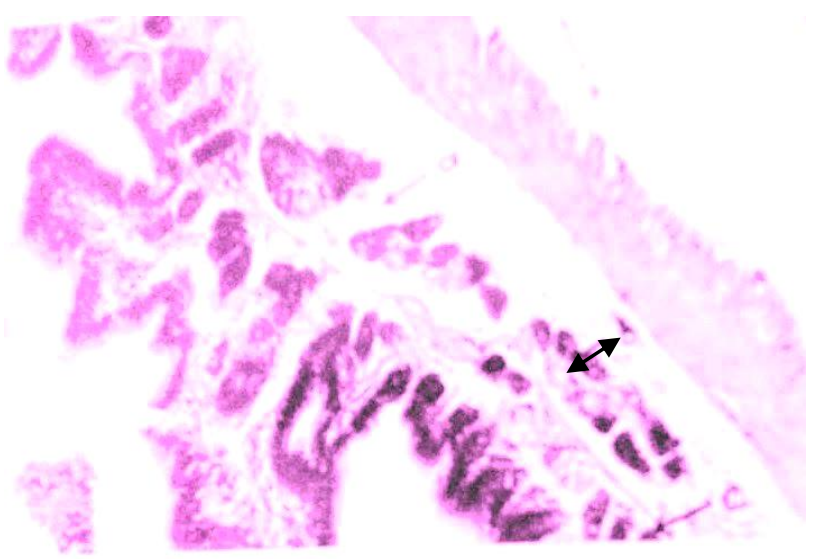

Fig. 8 Rabbit-Six weeks(H \&E stain x 80) Photomicrograph of T.S, of fourth part of duodenum showing

a) submucosa showing small patches of serous acini

b) less number of mucous acini (double arrow)

c) muscularis mucosae

\section{Conclusion:-}

Postnatal development of Brunner's glands in the rabbit were studied Total twenty one rabbits were sacrificed. The Brunner's gland in the rabbit at birth was represented by two cell layered tubular growth from the deeper parts of intestinal gland, branching into the submucosa of first and second of duodenum By the end of second week the glandular tissue extended to the fourth part of duodenum. Compactness of glands when traced at weekly intervals in the identical parts of duodenum showed marked increase upto sixth week The serous cells were differentiated in the terminal portions of tubules at birth but mucous acini started differentiated only after two weeks .At sixth week predomination of mucous acini in the first and second part of duodenum and of serous acini in the fourth part was seen while in the third part mucous and serous acini were almost in equal proportion This could be correlated to the greater need of alkanity in the vicinity of pyloric region which is the first to receive the acidic content of the stomach.

\section{References:-}

1. Wepfer JJ: Cicutae aquaticae historia et noxae. Basileae, 1679 
2. Brunner JC: De glandulis in intestino duodeno hominis detectis. Dissertation, Heidelberg, 1688

3. Brunner JC: Glandulae duodeni seu pancreas secondarium in intestino duodeno hominis primum abhinc in ahis quoque animalibus detectum. Heidelberg: University of Heidelberg, 1715.

4. Dobson J: Anatomical Eponyms, 2nd ed. London: E \& S Livingstone, 1962.

5. Middeldorpf AT: Disquisitio de Glandulis Brunnianis. Vratislavia, 1846.

6. FLOREY, H. W. \& HARDING, H. E. (1933). The functions of Brunner's glands and the pyloric end of the stomach. J. Path. Bact. 37, 431-453.

7. Florey HW, Harding HE: Further observations on the secretion of Brunner's glands. J Pathol Bacteriol 39: 255276, 1934.CrossRef

8. GROSSMAN, M. L. (1958). The glands of Brunner. Physiol. Rev. 38, 675-690

9. MOE, H. (1960). The ultrastructure of Brunner's glands of the cat. J. Ultrastruct. Res. 4, 58-72.

10. COCHRANE, W., DAVIEs, D. V., PALFREY, A. J. \& STOCKWELL, R. A. (1964). The histochemistry and electronmicroscopy of Brunner's glands in the guinea-pig. J. Anat. 98, 1-10.

11. FRIEND, D. S. (1965). The fine structure of Brunner's glands in the mouse. J. Cell Biol. 25, 563-576.

12. LEESON, C. R. \& LEESON, T. S. (1966). The fine structure of Brunner's glands in the rat. Anat. Rec.

13. BARTH, (1868). Beitrag zur Entwickelung der Darmwand. Besichte der Kaiserl Akademine der Wissenschaftin58, 129-136.

14. BRAND. (1877). Beitrage zur Entwickelung der Mogen und Darmwand. Verh. dphys. med. Gesse. Wurzb.9, 243-256.

15. JOHNSON, F. P. (1910). The development of the mucous membrane of the esophagus, stomach, and smallintestine in the human embryo. Am. J. Anat. 10, 521-561.

16. Obuoforibo,A .A. and Martin, B. F. (1977) postnatal growth of Brunner's gland in the mouse. J. Anat., 124,3,pp.779-790.

17. W. J. KRAUSE AND C. R. LEESON (1967) The origin, development an differentiation ofBrunner's glands in the rat J. Anat., 101, 2, pp. 309-320 309

18. Mann, V.A.D. Sasse and Crausemann W (1967) Beitrage Zur Function Sentwicklung duodenal Drusen heim Gold hamster Acta.Histochem.,28,p.89-9

19. Mohammadpour, A. A., 2011. Morphological and histochemical study of guinea pig duodenal submucosal glands. Bulg. J. Vet. Med., 14, No 4, 201-208.

20. Cooke.A.R. (1967) The glands of Brunner's Alimentary Canal.Volume II Secretion, Chap. 61,pp.1087-94

21. Gabe M.(1956) Contribution a 'l' histogenese desglandes salivaries chez la souris albinos Z. Zellfarsch. Mikroskop.Anat.45,p.74-95

22. Wolff H (1961)Embryological, Histochemical and experimental studies on Brunner's glands in the rabbit.Z.Zellforschung,53,p.829-56 